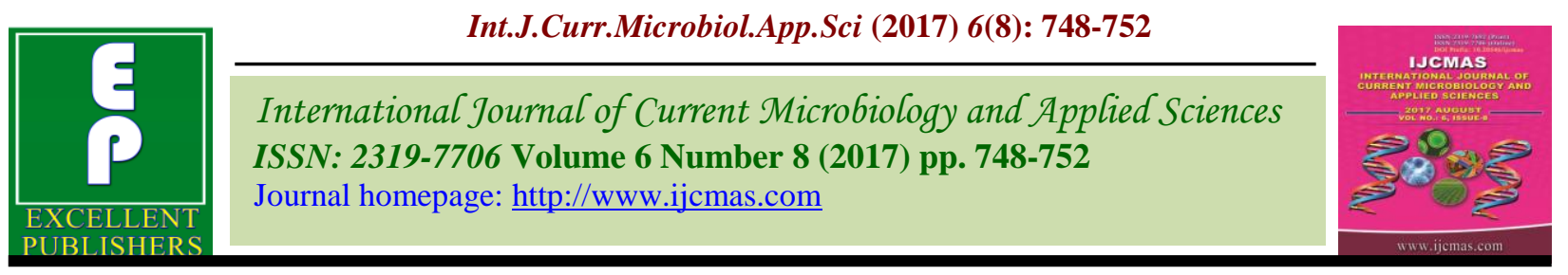

Original Research Article

https://doi.org/10.20546/ijcmas.2017.608.095

\title{
Effect of Seed Bed and Different Sources of Nitrogen on Growth and Yield of Barley (Hordeum vulgare L.)
}

\author{
Anand Kumar Singh ${ }^{*}$, P.J. George and Pradeep Prasad \\ Department of Agronomy, SHUATS, Allahabad, U. P., India \\ *Corresponding author
}

A B S T R A C T

Keywords

FIRB, RBD,

Grain yield,

Straw yield,

Barley, FYM,

Article Info

Accepted:

14 June 2017

Available Online:

10 August 2017

A field experiment was conducted during winter season of 2016-17 at Crop Research Farm, Department of Agronomy, SHUATS, Allahabad. The experiment compared the performance of barley variety "RD2035" under effect of seedbed and different sources of nitrogen on growth and yield of barley (Hordeun vulgare L.). Ten treatment combinations with three replications were laid out in Randomized Block Design. Two seed bed and five different sources of nitrogen were taken in to consideration. The results revealed that there was significantly and higher morphological attributes viz. plant height $(88.51 \mathrm{~cm})$, dry weight/ plant $924.12 \mathrm{~g}$ ), number of effective tillers $\mathrm{m}^{-1}$ row length (102.67) in treatment $\mathrm{T}_{7}$ (FIRB $+75 \% \mathrm{~N}$ through inorganic $+25 \% \mathrm{~N}$ through organic) and the same treatment recorded significantly higher grain yield $\left(5.70 \mathrm{t} \mathrm{ha}^{-1}\right)$ and also recorded highest straw yield $\left(8.06 \mathrm{t} \mathrm{ha}^{-1}\right)$ followed by treatment $\mathrm{T}_{8}(\mathrm{FIRB}+50 \% \mathrm{~N}$ through inorganic $+50 \% \mathrm{~N}$ through organic) and was found to be statistically at par to treatment $\mathrm{T}_{7}$ in most of the attributes recorded in the study.

\section{Introduction}

Barley (Hordeum vulgare L.) is the world's fourth most important cereal crop after wheat, rice and maize and is a hardy crop grown throughout the temperate, tropical and subtropical regions of the world. It is a rabi cereal crop is India and usually used as food for human beings and feed for animals and poultry birds (Singh et al., 2012). It is used for manufacture of malt extract which is further utilizes for brewing, distillation and baby foods as boost and horlicks, cocoa, malt drinks and also used in ayurvedic medicines. In the world barley was cultivated on 54 million hectares area with 124 million tones production in the year 2010-11 (FAOSTAT,
2012). In India, barley is grown on 0.78 million hectares area which is largely confined to Uttar Pradesh, Punjab and Haryana having 1.6 million tones production and $2167 \mathrm{~kg} / \mathrm{ha}$ productivity in the year 201011 (FAOSTAT, 2012). Each $100 \mathrm{~g}$ of barley grain comprises of $10.6 \mathrm{~g}$ protein, $2.1 \mathrm{~g}$ fat, 64 g carbohydrate, $50 \mathrm{mg}$ calcium, $6.0 \mathrm{mg}$ iron, $31 \mathrm{mg}$ vitamin $B_{1}, 0.10 \mathrm{mg}$ vitamin $B_{2}$ and 50 microgram folate (Vaugham et al., 2006). Both barley grains and straw are highly digestible compared to wheat due to absence of gluten. Hence, it is a valuable crop for health of mankind, cattle and poultry birds. Nitrogen is the main constituent of amino 
acids which are precursor to protein. So, malt barley grain yield, grain protein and kernel plumpness are the characteristics strongly related to available nitrogen (Grant, 2000). Lauer and Partridge (1990) observed that grain yield and protein content increased significantly with increase in nitrogen levels. There are various sources of nitrogen viz. chemical fertilizers, organic manures, green manuring crops and bio-fertilizers. As barley is mainly grown in arid and sub- marginal lands which are poor in fertility and deficient in either macro or micro elements.

Thus, organic manuring and nitrogen fertilization are considered among the most important cultural practices for increasing barley productivity and improved quality parameters. A combined use of organic and inorganic sources of plant nutrient not only enhances the production and quality of field crops but also helps in maintaining the fertility status of soil (Sharma et al., 2001).

The agronomic practices for malt barley are different from its grain crop. Methods of sowing, nitrogen levels and irrigation greatly affect the yield and quality of barley. Seed bed methods have a major influence on aeration, moisture and temperature of soil which in turn affect the yield and quality of crop. Keeping the above facts in view a study was undertaken to assess the effect of seed bed and different sources of nitrogen on growth and yield of barley (Hordeum vulgare L.) under Allahabad conditions of Uttar Pradesh.

\section{Materials and Methods}

The field experiment was carried out at Crop Research Farm, Department of Agronomy, SHUATS, Allahabad (U.P.) during rabi season of 2016-17 which is situated at $25^{\circ} 24^{\prime}$ 42 " N latitude, $81^{\circ} 50$ ' $56^{\prime \prime}$ E longitude and at an altitude of $98 \mathrm{~m}$ above the mean sea level.
The soil of the experimental field was sandy loam in texture with normal soil reaction and $\mathrm{EC}$, low in organic carbon, available nitrogen and available phosphorus and high in available potassium. The experiment was laid out in Randomized Block Design with 10 treatments each replicated thrice. The treatments consisted of two seed bed methods viz. Flat Bed (FB) and Furrow irrigated raised bed (FIRB) and five levels of different sources of nitrogen. The treatment combinations were viz. $\mathrm{N}_{1}-\mathrm{FB}+50 \% \mathrm{RDN}$ through inorganic, $\mathrm{N}_{2^{-}} \mathrm{FB}+75 \% \mathrm{~N}$ through inorganic $+25 \% \mathrm{~N}$ through organic, $\mathrm{N}_{3}-\mathrm{FB}+$ $50 \% \mathrm{~N}$ through inorganic $+50 \% \mathrm{~N}$ through organic, $\mathrm{N}_{4}-\mathrm{FB}+25 \% \mathrm{~N}$ through inorganic + $75 \% \mathrm{~N}$ through organic, $\mathrm{N}_{5}-\mathrm{FB}+100 \% \mathrm{~N}$ through organic, $\mathrm{N}_{6}-\mathrm{FIRB}+100 \% \mathrm{~N}$ through inorganic, $\mathrm{N}_{7^{-}}$FIRB $+75 \% \mathrm{~N}$ through inorganic $+25 \% \mathrm{~N}$ through organic, $\mathrm{N}_{8^{-}}$ FIRB $+50 \% \mathrm{~N}$ through inorganic $+50 \% \mathrm{~N}$ through organic, $\mathrm{N}_{9^{-}}$FIRB $+25 \% \mathrm{~N}$ through inorganic $+75 \% \mathrm{~N}$ through organic and $\mathrm{N}_{10^{-}}$ FIRB $+100 \% \mathrm{~N}$ through organic. Data for plant height, plant dry weight. Effective tillers/running row length, spike length, grains/ spike, grain yield and straw yield were recorded at harvest. Economics of barley was also calculated viz. gross return, net return and $\mathrm{BC}$ ratio to find out the most profitable combination among the 10 combination under study.

\section{Results and Discussion}

A perusal of table 1 clearly reveals that seed bed and different sources of nitrogen significantly differed with respect to plant height, plant dry weight and number of effective tillers at harvest (100DAS). The highest plant height $(88.51 \mathrm{~cm})$, maximum plant dry weight (24.12 g) and maximum number of effective tillers (102.67) were recorded in treatment $\mathrm{T}_{7}-(\mathrm{FIRB}+75 \% \mathrm{~N}$ through inorganic $+25 \% \mathrm{~N}$ through organic) followed by treatment $\mathrm{T}_{8}-(\mathrm{FIRB}+50 \% \mathrm{~N}$ 
through inorganic $+505 \mathrm{~N}$ through organic) which recorded plant height, plant dry weight and number of effective tillers as $85.36 \mathrm{~cm}$, $23.18 \mathrm{~g}$ and 101.67 respectively and were found to be at par to treatment $\mathrm{T}_{7}$.

The probable reason for recording maximum values for these parameters may be ascribed to better establishment of the plants and water utilization under fine tilth provided by FIRBS and better availability of nitrogen as well as micronutrients provided by organic manures at critical stages of crop growth. The increase in plant height and dry matter accumulation at harvest was mainly due to better availability of water throughout the crop season and also because of organic manure (FYM) which increases the water holding capacity of soil and thus the crop was not subjected to moisture stress at any stage. The other reason might be that nitrogen being a constituent of chlorophyll helps the plants for increase photosynthesis resulting into cell elongation and hence higher plant height and taller the plants greater is the dry matter/plant. These results are in accordance with those of Gayatri and Satwinderjit, (2016) and Khan et al., (2011)

An appraisal of table 2 clearly reveals that seed bed and different sources of nitrogen significantly differed with respect to spike length, grains/spike grain yield and straw yield.

Longest spike length $(8.45 \mathrm{~cm})$, maximum grains/spike (64.60), maximum grain yield $\left(5.70 \mathrm{t} \mathrm{ha}^{-1}\right)$ and straw yield $\left(8.06 \mathrm{t} \mathrm{ha}^{-1}\right)$ was recorded in treatment $\mathrm{T}_{7}$ followed by treatment $\mathrm{T}_{8}$ which recorded $8.20 \mathrm{~cm}, 62.07$, $5.37 \mathrm{t} \mathrm{ha}^{-1}$ and $7.33 \mathrm{t} \mathrm{ha}^{-1}$ of spike length, grains spike ${ }^{-1}$, grain yield and straw yield respectively and were statistically at par to the values recorded under treatment $T_{7}$.

Table.1 Effect of seed bed and different sources of nitrogen on growth parameter of barley

\begin{tabular}{|l|c|c|c|}
\hline Treatments & $\begin{array}{c}\text { Plant height } \\
(\mathrm{cm}) 100 \mathrm{DAS}\end{array}$ & $\begin{array}{c}\text { Plant dry weight } \\
(\mathrm{g}) 100 \mathrm{DAS}\end{array}$ & $\begin{array}{c}\text { Tillers/m row } \\
\text { length 100 DAS }\end{array}$ \\
\hline T1 FB+100\% N through inorganic & 81.48 & 20.60 & 91 \\
\hline T2 FB+75\% N through inorganic+25\% N through organic & 78.60 & 23.11 & 88.67 \\
\hline T3 FB+50\% N through inorganic+50\% N through organic & 82.93 & 23.90 & 89.33 \\
\hline T4 FB+25\% N through inorganic+75\% N through organic & 75.04 & 19.99 & 86.67 \\
\hline T5 FB+100\% N through organic & 79.67 & 21.78 & 85.67 \\
\hline T6 FIRB+100\% N through inorganic & 82.53 & 20.76 & 101.33 \\
\hline T7 FIRB+75\% N through inorganic+25\% N through organic & 88.51 & 24.12 & 102.67 \\
\hline T8 FIRB+50\% N through inorganic+50\% N through organic & 85.36 & 23.18 & 101.67 \\
\hline T9 FIRB+25\% N through inorganic+75\% N through organic & 75.88 & 19.26 & 93.67 \\
\hline T10 FIRB+100\% N through organic & 70.44 & 21.61 & 90.33 \\
\hline F test & $\mathrm{S}$ & $\mathrm{S}$ & $\mathrm{S}$ \\
\hline Sem & 2.96 & 0.90 & 2.14 \\
\hline CD (5\%) & 8.81 & 2.68 & 6.36 \\
\hline
\end{tabular}


Table.2 Effect of seed bed and different sources of nitrogen on yield attributes of Barley

\begin{tabular}{|c|c|c|c|c|}
\hline Treatments & $\begin{array}{l}\text { Spike length } \\
(\mathrm{cm}) 100 \text { DAS }\end{array}$ & $\begin{array}{c}\text { Grains spike }^{-1} \\
100 \text { DAS }\end{array}$ & $\begin{array}{l}\text { Grain yield } \\
\left(\mathrm{t} \mathrm{ha}^{-1}\right)\end{array}$ & $\begin{array}{c}\text { Straw yield } \\
\left(\mathrm{t} \mathrm{ha}^{-1}\right)\end{array}$ \\
\hline $\mathrm{T} 1 \mathrm{FB}+100 \% \mathrm{~N}$ through inorganic & 7.37 & 57.67 & 4.50 & 6.24 \\
\hline $\mathrm{T} 2 \mathrm{FB}+75 \% \mathrm{~N}$ through inorganic $+25 \% \mathrm{~N}$ through organic & 8.05 & 61.93 & 3.93 & 5.70 \\
\hline $\mathrm{T} 3 \mathrm{FB}+50 \% \mathrm{~N}$ through inorganic $+50 \% \mathrm{~N}$ through organic & 8.15 & 62.03 & 3.83 & 5.44 \\
\hline $\mathrm{T} 4 \mathrm{FB}+25 \% \mathrm{~N}$ through inorganic $+75 \% \mathrm{~N}$ through organic & 7.55 & 56.93 & 4.0 & 5.67 \\
\hline $\mathrm{T} 5 \mathrm{FB}+100 \% \mathrm{~N}$ through organic & 7.06 & 55.73 & 4.03 & 5.89 \\
\hline T6 FIRB+100\% $\mathrm{N}$ through inorganic & 7.60 & 58.40 & 4.97 & 7.31 \\
\hline T7 FIRB $+75 \% \mathrm{~N}$ through inorganic $+25 \% \mathrm{~N}$ through organic & 8.45 & 64.60 & 5.70 & 8.06 \\
\hline $\mathrm{T} 8 \mathrm{FIRB}+50 \% \mathrm{~N}$ through inorganic $+50 \% \mathrm{~N}$ through organic & 8.20 & 62.07 & 5.37 & 7.33 \\
\hline T9 FIRB $+25 \% \mathrm{~N}$ through inorganic $+75 \% \mathrm{~N}$ through organic & 6.79 & 52.20 & 3.87 & 5.43 \\
\hline T10 FIRB+100\% N through organic & 6.71 & 49.20 & 3.37 & 4.77 \\
\hline F test & $\mathrm{S}$ & $\mathrm{S}$ & $\mathrm{S}$ & $\mathrm{S}$ \\
\hline Sem & 0.30 & 1.91 & 0.32 & 0.38 \\
\hline $\mathrm{CD}(5 \%)$ & 0.91 & 5.67 & 0.95 & 1.12 \\
\hline
\end{tabular}

Table.3 Economics of seed bed and different sources of nitrogen on barley

\begin{tabular}{|l|c|c|c|c|}
\hline Treatments & $\begin{array}{c}\text { Cost of } \\
\text { cultivation ₹/ha }\end{array}$ & $\begin{array}{c}\text { Gross return } \\
\text { ₹/ha }\end{array}$ & $\begin{array}{c}\text { Net return } \\
\text { ₹/ha }\end{array}$ & \begin{tabular}{c} 
B:C ratio \\
\hline T1 FB+100\% N through inorganic
\end{tabular} \\
26784.00 & 73845.00 & 47061.34 & 2.76 \\
\hline T2 FB+75\% N through inorganic+25\% N through organic & 29535.00 & 58627.50 & 29092.48 & 1.99 \\
\hline T3 FB+50\% N through inorganic+50\% N through organic & 32322.00 & 63237.50 & 30915.18 & 1.96 \\
\hline T4 FB+25\% N through inorganic+75\% N through organic & 35097.00 & 66010.00 & 30912.84 & 1.88 \\
\hline T5 FB+100\% N through organic & 37560.00 & 67037.50 & 29477.50 & 1.78 \\
\hline T6 FIRB+100\% N through inorganic & 26784.00 & 82812.50 & 56028.84 & 3.09 \\
\hline T7 FIRB+75\% N through inorganic+25\% N through organic & 29535.00 & 94005.00 & 64469.98 & 3.18 \\
\hline T8 FIRB+50\% N through inorganic+50\% N through organic & 32322.00 & 87772.50 & 55450.18 & 2.72 \\
\hline T9 FIRB+25\% N through inorganic+75\% N through organic & 35097.00 & 63697.50 & 28600.34 & 1.81 \\
\hline T10 FIRB+100\% N through organic & 37560.00 & 55592.50 & 18032.50 & 1.48 \\
\hline
\end{tabular}

The probable reason for recording higher values can be ascribed to better establishment of plants and maximum utilization of water under fine tilth provided by FIRBS. The higher yield attributes in FIRBS may also be due to higher dry matter production and translocation and the conversion of photosynthates in to reproductive parts.

Fine tilth and better aeration causing less penetration impedance may also be responsible for better root development resulting in adequate absorption of nutrients thereby producing higher yield attributes. The nitrogen levels in barley manifested significant impact on number of effective tillers, spike length, no. of grains spike $^{-1}$, grain yield and straw yield and can be ascribed to better availability of nitrogen and other nutrients through organic manure resulting into better translocation of photosynthates from source to sink. Similar findings have also been reported by Idnani and Kumar, (2012) and Singh et al., (2012).

\section{Economics}

A perusal of table 3 clearly shows that maximum gross return, net return and $\mathrm{BC}$ ratio was attained in treatment $\mathrm{T}_{7}$ (FIRB + $75 \% \mathrm{~N}$ through Inorganic $+25 \% \mathrm{~N}$ through organic) to a tune of Rs. 94005.00, Rs. 
64470.00 and 3.18 respectively followed by treatment $T_{8}$ which registered gross return, net return and $\mathrm{BC}$ ratio as Rs. 87772.50, Rs. 55450.50 and 2.72 respectively.

It can be concluded from the above findings that FIRB $+75 \% \mathrm{~N}$ through inorganic $+25 \%$ $\mathrm{N}$ through organic was the best treatment for growing barley in Allahabad region of Uttar Pradesh as it gave maximum net return and $\mathrm{BC}$ ratio. However, these results are based on one year trial further research are needed to make clear cut recommendation for maximum production and profitability of barley (Hordeum vulgare L.) in this region.

\section{References}

El-Lattiel, E.A. Abd (2014).Effect of integrated use of farm yard manure (FYM) and chemical fertilizers (NPK) on Productivity of bread wheat under arid conditions. International Journal of Advanced Research in Engineering and Applied Sciences. 3(12): 22-27

Gayatri, V., Satwinderjit, K. (2016).Effect of Nitrogen levels alone and in combination with Farm Yard Manure, Potassium and Phosphorus on grain yield. International Journal of
Agriculture Sciences, 8(47):1974-1975.

Grant, D.J. (2000). Nitrogen fertilization of dry land malt barley for yield and quality. Fertilizer Facts. Pp. 24

Idnani, L.K., and Kumar, A. (2012). Relative efficiency of different irrigation schedules for conventional, ridge and raised bed seeding of wheat (Triticum aestivum). Indian Journal of Agronomy, 57(2): 148-151.

Lauer, J.G. and Partridge, J.R. (1990). Planting date and nitrogen rate effect on spring malting barley. Agronomy Journal, 82:1083-88.

Singh, J., Mahal, S.S. and Manhas, S.S. (2012). Effect of sowing methods, nitrogen levels and irrigation scheduling on yield and quality of malt barley (Hordeum vulgare L.) Indian Journal of Agrnomy, 57(3): 259-264.

Sharma, R. P., Sure, V. K. and Datt, N. (2001). Integrated nutrient management in summer barley (Hordeum vulgare L.) in a cold desert of Himachal Pradesh. Ind. J. Agri. Sci., 71: 752-755.

Vaughan, J. G., Judd, P.A. and Bellamy, D. (2006). The oxford book of health foods. http://books. Google.co.in/books p 37.

\section{How to cite this article:}

Anand Kumar Singh, P.J. George and Pradeep Prasad. 2017. Effect of Seed Bed and Different Sources of Nitrogen on Growth and Yield of Barley (Hordeum vulgare L.). Int.J.Curr.Microbiol.App.Sci. 6(8): 748-752. doi: https://doi.org/10.20546/ijcmas.2017.608.095 